УДК 612.766.1: 63.321.933

\title{
ASSESSMENT OF FUNCTIONAL STATE AND ADAPTATION RESERVES OF MACHINE OPERATORS IN AGRICULTURE WITH DIFFERENT WORK EXPERIENCE IN THE PROFESSION
}

\author{
S.S. Raikin, T.A. Novikova \\ FBSI "Saratov Scientific Research Institute of Agricultural Hygiene" of the Federal Service for Consumer Rights \\ Protection and Human Well-Being Surveillance, Russian Federation, Saratov, 1A Zarechnaya St., 410022
}

The results of hemodynamic parameters' evaluation (blood pressure, heart rate, minute volume of blood, total peripheral vascular resistance) and adaptation (adaptive capacity of the circulatory system, the index of physical condition, body mass index) to job strains in machine operators of agriculture with a different experience in the profession are presented. It was found that $27 \%$ of the patients - machine operators were in a state of unsatisfactory adaptation and $18.8 \%$ in the state of failure of adaptation options when functional body reserves were sharply reduced, indicating that the work in hazardous conditions resulted in a significant deterioration of the functional state of exhaustion and adaptation reserves. It was found that the professional experience of 10 years or more is a risk factor for the health of machine workers in agriculture, causing the violation of functional state and exhaustion of adaptive reserves of an organism, as evidenced by a statistically significant correlation between the indicators of functional status and work experience in the profession.

Key words: agricultural machine operators, working conditions, work experience in the profession, functional state, organism adaptive capacity.

To increase production and recycling of the leading domestic plant products including production of grains is one of the priority strategic objectives of Russia's food supply security, according to the 2013-2020 Program for the Development of Agriculture and Regulation of the Agricultural, Raw Material, and Food Market.

Tractor drivers/machine operators (agricultural operators) involved in seedbed preparation, grain planting, and harvesting form the main workforce in grain planting; they operate various agricultural equipment: tractors with trailing or mounted implements, self-propelled machines, and combine harvesters. Field operations are carried out on a continuous basis and on a tight schedule due to the climate and the time of plant growth. For this reason, successful performance of the "operator-machine" system is very important, and human is what could become the "weak link".

Labor activity of agricultural operators takes place in a hazardous environment characterized by elevated noise and vibration levels, microclimatic discomfort, dustiness and industrial pollu- tion, physical and emotional stress. Additionally, more than $70 \%$ of the work equipment has reached a high level of deterioration which exacerbates the hazardous impact of the labor factors on the employees' health. Previously, it was determined that the impact of labor factors depended on the type of labor activity, brand of the equipment, and useful life, and corresponded to the 1-4 levels (classes 3.1-3.4) in terms of deviation from the hygienic standards.

Hazardous labor conditions may become a health risk factor causing occupational and general illnesses which could result in temporary or permanent loss of ability to work or incapability among the agricultural operators $[2,3]$.

In view of the above, preservation of health and labor longevity among this group of agricultural workers requires ensuring their labor safety. Based on the medical knowledge, the solution to this issue lays not only in organizing the labor condition in accordance with the sanitary standards, but also in carrying out measures aimed to prevent overstressing and reduce the physiological cost of the labor process $[2,4]$.

(C) Raikin S.S., Novikova T.A., 2015

Novikova Tamara Anatolievna - Candidate of Biological Sciences, Associate Professor, Head of the Laboratory of Occupational Hygiene in Agriculture and Processing Industry (e-mail: novikovata-saratov@ yandex.ru; tel. 8 (845-2) 34-71-84).

Raikin Sergey Sergeevich - Junior Researcher, Laboratory of Occupational Hygiene in Agriculture and Processing Industry (e-mail: Rser3001@ yandex.ru; tel. 89172013553). 
Here it is particularly important to analyze the functional state, identify the levels of stress and overstress of the regulatory mechanisms, decreased adaptation potential of the operators' organisms due to the labor activity, and, as a result, to diagnose the state of health of the individuals employed as tractor drivers/agricultural operators in order to recommend a course of preventative treatment.

The objective of the assessment was to assess the functional state and level of adaption to professional stress among agricultural operators.

\section{Scope and method of the study.}

The study of the functional body state of the agricultural operators was conducted before the start of a work shift, at the grain farms located in Saratov Region. The study examined 85 operators aged 30-59 (mean value 42,4 $\pm 11,1$ ) with a length of service ranging 3-35 years (mean value $19,6 \pm 11,6)$. Following the requirements of biomedical ethics, informed consent was obtained from all the study participants.

In the course of the study, anthropometric measurements (height, body mass, body mass index) were taken. To assess the state of physical health, the Physical Component Summary (PCS) was used by Porigova et al (1986). PCS was calculated according to the formula:

$700-(3 * \mathrm{HR})-(0,8333 * \mathrm{SBP})-(1,6667 * \mathrm{DBP})-(2,7 * \mathrm{~A})+(0,28 * \mathrm{M})$ $\mathrm{PCS}=$

$350-(2,6 * \mathrm{~A})+(0,21 * \mathrm{H})$

where HR - is Heart Rate per minute; SBP - systolic blood pressure, мм.рт.ст.; DBP - diastolic blood pressure, mm Hg; A - age, years old; $\mathrm{M}$ body mass, $\mathrm{kg} ; \mathrm{H}-$ height, $\mathrm{cm}$. The state of physical health of the surveyed operators was assessed using the following scale: low level- less than 0,375 ; below average level - from 0,376 to 0,525 ; average level - from 0,526 to 0,675 ; above average - from 0,676 to 0,825 ; highest level of the physical state - more than 0,826 [5].

They assessment of the physical state of health was based on the indicators of the cardiovascular system which play the most important role in the adaptive activity of an organism in general. We measured the systolic blood pressure (SBP) and diastolic blood pressure (DBP), heart rate (HR), calculated pulse pressure (PP), average flowing pressure (AFP), cardiac output (CA), and general peripheral resistance (GPR).

To assess the adaptive capabilities of a functioning organism, we used the adaptation potential (AP) of the blood system by Bayevsky R.M., Berseneva A.P. (1997).
The level of adaptation potential was calculated according to the following formula: $\mathrm{AP}=0,011 * \mathrm{HR}+0,014 * \mathrm{SBP}+0,008 * \mathrm{DBP}+$ $+0,014 * A+0,09 * M-(0,009 * H+0,27)$, where $\mathrm{HR}$ - heart rate per minute ; SBP and DBP - systolic and diastolic blood pressure, $\mathrm{mm} \mathrm{Hg}, \mathrm{A}-$ age, years; $\mathrm{M}$ - body mass, $\mathrm{kg} ; \mathrm{H}$ - height, $\mathrm{cm}$.

The formula developed by the authors suggests that individual health performance be calculated as followings: if AP is lower than 2.59 points - sufficient functional capabilities, satisfactory adaptation; AP ranging from 2.60 to 3.09 points - functional stress of the adaptation mechanisms; AP ranging from 3.10 to 3.49 points - reduced adaptive possibilities, unsatisfactory adaptation; AP higher than 3.50 - sharp reduction of the functional capabilities, adaptation failure [6].

The study results were statistically processed using Microsoft spreadsheets and Statistica10. We calculated the mean (M) and standard deviation (SD), median (Me), $25^{\text {th }}$ and $75^{\text {th }}$ percentile. The statistical significance of the levels of indicators in sub-groups was determined using the U-test. Additionally, we calculated Spearmen's rank-order correlation $\left(\mathrm{r}_{\mathrm{s}}\right)$. The differences were considered statistically significant at $p<0,05$.

\section{Results}

The analysis of the study results showed that the physical and functional state of the operators at the moment of examination were unsatisfactory. $31 \%$ of the operators had a low level of the physical state index, and 25\% - a below average level. The study showed that $33 \%$ of the operators were overweight, and $15 \%$ had level 1 obesity. Excessive weight is known to be one of the risk factors for arterial hypertension. Mean group values of the systolic blood pressure and pulse pressure in the operators under study totaled $148 \pm 20,3 \mathrm{~mm} \mathrm{Hg}$ and $63,0 \pm 17,2 \mathrm{~mm} \mathrm{Hg}$, respectively (under diastolic blood pressure $85,0 \pm 11,9 \mathrm{~mm} \mathrm{Hg}$ ) which exceeded the physiological standards and was considered to be a sign of breakdown in the adaptive capabilities of the cardiovascular system. The mean group value of the average flowing pressure of $106 \pm 12.9$ (median and quartile $105.3 \mathrm{~mm} \mathrm{Hg}$, $97.3 \mathrm{~mm} \mathrm{Hg}$, and $113.3 \mathrm{~mm} \mathrm{Hg}$, respectively) also indicates disruption in the functioning of the blood circulation regulating mechanism.

Correlation analysis proved the dependency between elevated arterial blood pressure and excessive body weight - we established a positive correlation between the body mass index and systolic, diastolic, and average dynamic arterial pressure $\left(r_{s}=0.35\right.$; $r_{s}=0.29$ and $r_{s}=0.36$ respectively, $p<0.05$ ). 
Assuming that the level of stress of the regulatory systems is an integral response of an organism to the combined impact of hazardous factors, we paid close attention to the assessment of the index of functional changes by R.M. Bayevsky and A.P. Berseneva (1997).

The mean group level of the Functional Changes Index in the operators under study totaled $3.04 \pm 0.50$ points which corresponded with functional stress. At the same time, $27 \%$ of the operators under study showed signs of unsatisfactory adaptation, and $18.8 \%$ showed signs of adaptation failure when the functional reserves of the organism have dropped significantly; according to the adaptation theory, this indicates that the organism has to turn on additional internal reserves to ensure consistent functioning of the organism under this condition. The operators with signs of unsatisfactory adaptation, particularly those with signs of adaptation failure form the high risk group for the development of pathological conditions and acute illnesses or acute exacerbation of a chronic disease.

To establish the dependency between the adaptive reserves and length of service, the operators under study were divided into 4 subgroups with various length of service: subgroup 1- less than 10 years; subgroup $2-10-19$ years, subgroup $3-$ 20-29 years, and subgroup 4 - more than 30 years.

It was established that the body mass index increases with more years of service which may be explained by aging; however, the differences in the body mass index values were not statistically significant (see Table below).
$62,5 \%$ of the operators with the BMI that conforms with the standards were from subgroup 1 less than 10 years of professional service. In subgroup 2, there were less people with a standard BMI - 57.7\%; moreover, $11.5 \%$ of the examined operators had a BMI that indicated level 1 obesity. In subgroups 3 and 4 , level 1 obesity was registered in $24 \%$ and $22 \%$ respectively; $32 \%$ and $33 \%$ of the examined had an excessive BMI.

The comparison of the hemodynamics indicators in operators with various lengths of services showed that the individuals with a shorter length of service had more meaningful indicators. The levels of systolic and diastolic blood pressures were going up with longer service, and were the highest in subgroup 4; were significantly different $(p<0,05-0,01)$ as compared to subgroup 1 . It was determined that $50 \%$ of the operators in subgroups 1 and 2 had elevated systolic blood pressure. In subgroup 1, prevailing SBP was $140-159$ (33\%); in subgroup 2, it was at 160-179 (23\% of the examined operators). In subgroup 3 , $40 \%$ had elevated systolic blood pressure, and in subgroup $4-89 \%$. It is noteworthy that the operators with $30+$ years of professional experience had the systolic blood pressure at $140-159 \mathrm{~mm}$ $\mathrm{Hg} ; 40 \%$ had the blood pressure at $160-179 \mathrm{~mm}$ $\mathrm{Hg}$, and $11 \%$ had SBP at higher than $180 \mathrm{mmHg}$. In subgroup $4,45 \%$ of the examined operators had elevated diastolic blood pressure. The minute volume and peripheral vascular resistance significantly differed $(p<0.03)$ as compared to the other subgroups. The identified changes in the hemodynamics indicators in the examined operators

Indicators of the functional state of health and adaptive reserves of the operators with various lengths of service

\begin{tabular}{|c|c|c|c|c|c|c|c|c|}
\hline \multirow{3}{*}{ Indicators } & \multicolumn{8}{|c|}{ Subgroups in terms of length of servce } \\
\hline & \multicolumn{2}{|c|}{$\begin{array}{c}\text { Subgroup } 1 \\
n=16\end{array}$} & \multicolumn{2}{|c|}{$\begin{array}{c}\text { Subgroup } 2 \\
n=26\end{array}$} & \multicolumn{2}{|c|}{$\begin{array}{c}\text { Subgroup } 3 \\
n=25\end{array}$} & \multicolumn{2}{|c|}{$\begin{array}{c}\text { Subgroup } 4 \\
n=18\end{array}$} \\
\hline & $\mathrm{M}$ & $\mathrm{SD}$ & $\mathrm{M}$ & $\mathrm{SD}$ & $\mathrm{M}$ & $\mathrm{SD}$ & $\mathrm{M}$ & SD \\
\hline Age, years & 29,1 & 5,8 & 45,4 & 6,2 & 38,0 & 8,1 & 56,4 & 3,4 \\
\hline Length of service, years & 4,2 & 2,4 & 13,6 & 2,6 & 23,1 & 3,0 & 37,2 & 4,3 \\
\hline Body mass, $\mathrm{kg}$ & 71,6 & 11,8 & 73,7 & 13,6 & 77,8 & 15,3 & 78,0 & 12,1 \\
\hline BMI, $\mathrm{kg} / \mathrm{m}^{2}$ & 23,6 & 3,0 & 24,9 & 4,2 & 26,3 & 4,9 & 26,2 & 3,6 \\
\hline $\mathrm{SBP}, \mathrm{mm} \mathrm{Hg}$ & 140,8 & 13,5 & $148,4 * *$ & 25,7 & $145,0 * *$ & 17,4 & $158,2 *$ & 17,2 \\
\hline $\mathrm{DBP}, \mathrm{mm} \mathrm{Hg}$ & 77,7 & 13,9 & 84,3 & 11,5 & $85,2 * *$ & 9,8 & $92,2 *$ & 9,8 \\
\hline $\mathrm{HR}$, beats per minute & 78,6 & 11,1 & 74,3 & 10,0 & 76,8 & 9,7 & 76,5 & 14,3 \\
\hline $\mathrm{PP}, \mathrm{mm} \mathrm{Hg}$ & 63,1 & 17,0 & 64,0 & 21,1 & 59,8 & 14,4 & 65,9 & 15,6 \\
\hline $\mathrm{AFP}, \mathrm{mm} \mathrm{Hg}$ & 98,7 & 11,2 & $105,7 * *$ & 14,5 & $105,1 * *$ & 10,9 & $114,2 *$ & 10,4 \\
\hline $\mathrm{CA}, \mathrm{Ml} / \mathrm{min}$ & 4922,0 & 1304,6 & $4020,9 * ; * *$ & 994,8 & $3626,2 * ; * *$ & 996,7 & $2966,0 *$ & 733,2 \\
\hline GPR, dyne & 1750,9 & 661,9 & $2259,3 * ; * *$ & 755,4 & $2512,8 * ; * *$ & 852,4 & $3280,4^{*}$ & 999,4 \\
\hline AP, points & 2,675 & 0,367 & $2,947 * *$ & 0,563 & $3,073 * ; * *$ & 0,403 & $3,462 *$ & 0,334 \\
\hline PCS & 0,507 & 0,171 & $0,446 * *$ & 0,201 & $0,392 * ; * *$ & 0,136 & $0,227 *$ & 0,214 \\
\hline
\end{tabular}

* - differences are statistically significant as compared to subgroup 1

** - differences are statistically significant as compared to subgroup 4 
indicate a growing disagreement among the blood regulating mechanisms with longer professional experience and, accordingly, older age which may be considered a manifestation of pre-pathological conditions. The PSC assessment of the operators with various lengths of services showed that in subgroups 1 and 2, 25\% and $26 \%$ of the operators respectively had a low level of the physical condition. The physical state index was registered as low among the operators who were older and had longer career; in subgroup 3, the index was registered as low in $48 \%$ of the examined; in subgroup $4-$ in $72 \%$ of the examined.

The values of adaptation potential were elevated across all the subgroups which indicated adaptation disorder. After 10 years of professional service, a sharp increase - more than by 3.5 times - in the amount of the examined with unsatisfactory adaptation, as compared to subgroup 1 (up to $23 \%$ of the examined); the AP levels in the operators indicated adaptation failure. With longer professional service, the number of cases of adaptation failure increased. For example, the number of such individuals in subgroup 3 with the length of service of 20-29 years totaled 16\%; in subgroup
4 with $30+$ years of professional service, - 50\%. The level of adaptation potential in subgroups 3 and 4 is significantly higher as compared to subgroup 1 with 10 years of professional service ( $p=0.003594$ and $p=0.000001$, respectively).

\section{Conclusion}

In the course of the study it was determined that the agricultural operators exposed to a series of harmful work conditions have a poor functional state of health and lower adaptation potential exacerbated by longer professional service.

Based on the obtained data, it may be concluded that $10+$ years of professional service is a health risk factor for the agricultural operators responsible for poor functional state of health and depletion of adaptation reserves of the organism which is confirmed by the statistically significant correlations between the indicators of the functional state of health and the length of service in the profession.

The study results indicate the importance of development and implementation of preventative measures aimed to resurrect the functional reserves of the agricultural operators in the process of labor activity.

\section{References}

1. Novikova T.A. et al. Professionalnyj risk dlya zdoroviya rabotnikov sel'skogo hozjajstva, gigienicheskie aspekty ego ocenki i upravlenija. Professional risk for the health of agricultural workers, hygienic aspects of its assessment and management (review of literature) /T.A. Novikova, V.F. Spirin, N.A. Mikhailova, V.M. Taranova // Medicina truda i promyshlennaja ekologiya. - 2012. - № 5. - p. 22-28.

2. Spirin V.F., Novikova T.A., Gershtein E.G. Gigienicheskie problemy upravlenija professional'nymi riskami u rabotnikov selskogo hozyaistva Hygienic issues of managing the professional risks faced by the agricultural workers // Zdravoohranenie Rossiiskoi Federatsii - 2008г. - № 1. - p. 19-20.

3. Novikova T.A. et al. Uslovija truda kak faktory professionalnogo riska funkcionalnyh narushenij $u$ mehanizatorov selskogo hozyaistva. Labor conditions as professional risk factors leading to fundamental damages in the agricultural operators/T.A. Novikova, S.S. Raikin, V.S. Buyanov, V.F. Spirin, R.B. Rakhimov //Analiz riska zdoroviu. - 2014. - № 2. - p. 48-53.

4. Melentiev A.V. Modhody k profilaktike kardiovaskuljarnogo riska u rabochih promyshlennyh predpriyatijy. Approaches to the prevention of cardiovascular risk in the industrial workers. // Zdorovie naselenija i sreda obitaniya. - 2012. - № 9 (234). - p. 12-13.

5. Pirogova E.A., Ivashhenko L.Ja., Strapko N.P. Vliyanie fizicheskih uprazhneniy na rabotosposobnost i zdorovie cheloveka. Health benefits of physical exercises for the health of humans. - Kiev: Zdorovie, 1986. - p. 4-143.

6. Baevskiy R. M. Ocenka adaptacionnyh vozmozhnostej organizma i risk razvitija zabolevanij. Assessment of the adaptation opportunities of the organism and disease risks / R.M. Baevskiy, A.P. Berseneva. - M.: Meditsina, 1997. 